\title{
Pengawasan Preventif sebagai Kontrol Pusat terhadap Daerah di Era Reformasi
}

\author{
Derita Prapti Rahayu*
}

\begin{abstract}
Abstrak
Era reformasi ditandai dengan adanya pemberian hak, wewenang, dan kewajiban bagi daerah otonom untuk mengatur dan mengurus sendiri urusan pemerintahan serta kepentingan masyarakat setempat sesuai dengan peraturan perundang-undangan. Penyelenggaraan pemerintahan daerah diarahkan untuk mempercepat terwujudnya kesejahteraan masyarakat melalui peningkatan pelayanan, pemberdayaan peran serta masyarakat, serta peningkatan daya saing daerah dengan memperhatikan prinsip demokrasi, pemerataan, keadilan, dan kekhasan suatu daerah dalam sistem Negara Kesatuan Republik Indonesia. Dalam Undang-Undang Nomor 23 Tahun 2014 tentang Pemerintahan Daerah, hubungan kewenangan antara pemerintah pusat dengan pemerintah daerah berimplikasi pada praktik pengawasan, khususnya pengawasan preventif yang cenderung terlalu ketat. Hal ini cenderung melemahkan otonomi dan resentralisasi.
\end{abstract}

Kata kunci: pengawasan preventif, kewenangan pusat-daerah, kontrol pusat-daerah, era reformasi, otonomi daerah.

\section{Preventive Control of Central Government to Local Government in Reformation Era}

\begin{abstract}
The reformation era marked by granting of rights, powers, obligations and autonomous regions to set up and manage the affairs and interests of their own local community review according to the rules. Directing local administration to accelerate the establishment of public welfare through service improvement, empowerment, and community participation, as well as increasing competitiveness of the region viewed with principles of democracy, equality, justice, and the peculiarities of System The Unitary State The Republic Of Indonesia. In Law Number 23 of 2014 Concerning Local Government, the relation between central and local government, effects on preventive control, supervision particularly felt tend to be too tight. Too set how local government should be careful central government authority. It tends to weaken the autonomy and recentralisation.
\end{abstract}

Keywords: the preventive control, authority of center-local, control of center-local, the reform era, local autonomy.

PADJADJARAN Jurnal IImu Hukum Volume 2 Nomor 3 Tahun 2015 [ISSN 2460-1543] [e-ISSN 2442-9325]

* Dosen Fakultas Hukum Universitas Bangka Belitung, Jl. Merdeka No. 4 Pangkalpinang, deritapraptir@ yahoo.com, S.H. (Universitas Darul Ulum ), M.H. (Universitas Diponegoro). 


\section{A. Pendahuluan}

Pada Pasal 1 Undang-Undang Dasar Negara Republik Indonesia Tahun 1945 (UUD 1945) dinyatakan bahwa negara Indonesia adalah negara kesatuan yang berbentuk republik. Konsekuensi logis sebagai negara kesatuan adalah dibentuknya Pemerintah Negara Indonesia sebagai pemerintah nasional untuk pertama kalinya, kemudian pemerintah tersebut membentuk daerah sesuai ketentuan peraturan perundang-undangan. Selanjutnya, pada Pasal 18 ayat (2) dan ayat (5) UUD 1945 dinyatakan bahwa pemerintahan daerah berwenang untuk mengatur dan mengurus sendiri urusan pemerintahan menurut asas otonomi dan tugas pembantuan, serta diberikan otonomi yang seluas-luasnya. Pemberian otonomi yang seluas-luasnya kepada daerah diarahkan untuk mempercepat terwujudnya kesejahteraan masyarakat melalui peningkatan pelayanan, pemberdayaan, dan peran serta masyarakat. Melalui otonomi luas dalam lingkungan strategis, daerah juga diharapkan mampu meningkatkan daya saing dengan memperhatikan prinsip demokrasi, pemerataan, keadilan, keistimewaan dan kekhususan, serta potensi keanekaragaman daerah dalam sistem Negara Kesatuan Republik Indonesia (NKRI). ${ }^{1}$

Pemberian otonomi yang seluas-seluasnya kepada daerah dilaksanakan berdasarkan prinsip negara kesatuan. Dalam negara kesatuan, kedaulatan hanya ada pada pemerintahan pusat dan tidak ada kedaulatan pada daerah. Oleh karena itu, seluas apa pun otonomi yang diberikan kepada daerah, tanggung jawab akhir penyelenggaraan pemerintahan daerah tetap berada di pemerintah pusat. Fungsi pemerintahan daerah pada negara kesatuan merupakan bagian dari pemerintahan pusat. Sejalan dengan hal tersebut, kebijakan yang dibuat dan dilaksanakan oleh pemerintah daerah merupakan bagian integral dari kebijakan nasional. Perbedaannya terletak pada bagaimana memanfaatkan kearifan, potensi, inovasi, daya saing, dan kreativitas daerah untuk mencapai tujuan nasional tersebut di tingkat lokal yang pada gilirannya akan mendukung pencapaian tujuan nasional secara keseluruhan. ${ }^{2}$

Salah satu upaya mewujudkan tujuan negara adalah dengan mengubah pola pembangunan dari sentralistis menuju ke desentralistis atau yang dikenal dengan era otonomi daerah. ${ }^{3}$ Era otonomi daerah pada hakikatnya merupakan tatanan baru bagi pemerintahan Indonesia untuk mewujudkan kesejahteraan bagi masyarakat

1 Penjelasan umum tentang hubungan pemerintah pusat dan daerah ditetapkan Undang-Undang Nomor 23 Tahun 2014 tentang Pemerintahan Daerah (UU Pemda 2014).

2 Ibid.

3 Otonomi daerah menurut ketentuan Pasal 1 angka 6 UU Pemda 2014, “Hak, wewenang, dan kewajiban daerah otonom untuk mengatur dan mengurus sendiri Urusan Pemerintahan dan kepentingan masyarakat setempat dalam sistem Negara Kesatuan Republik Indonesia". Daerah otonom menurut ketentuan Pasal 1 angka 12 UU Pemda 2014, "Kesatuan masyarakat hukum yang mempunyai batas-batas wilayah yang berwenang mengatur dan mengurus Urusan Pemerintahan dan kepentingan masyarakat setempat menurut prakarsa sendiri berdasarkan aspirasi masyarakat dalam sistem Negara Kesatuan Republik Indonesia". 
setempat, ${ }^{4}$ termasuk penyerahan beberapa kewenangan pusat kepada daerah dalam bidang peraturan atau regulasi daerah. ${ }^{5}$

Dari sisi historis, otonomi daerah sebenarnya bukanlah hal yang baru di Indonesia. Ketika kerajaan-kerajaan di nusantara masih berjaya, raja merupakan pusat kekuasaan. Dalam era pemerintahan monarki tersebut belum dikenal konsep desentralisasi sebagai perwujudan otonomi daerah. Konsep desentralisasi baru dikenal ketika pemerintahan Hindia Belanda menginjakkan dan menancapkan kuku kolonialisme di Indonesia. ${ }^{6}$ Berbicara tentang otonomi daerah tidak dapat dipisahkan dari perjalanan peraturan perundang-undangan yang pernah diterapkan di Indonesia, sejak era pemerintahan kolonial Belanda hingga Indonesia merdeka sekarang. ${ }^{7}$

Pada tanggal 23 Juli 1903, undang-undang mengenai desentralisasi pemerintah di Hindia Belanda bernama De Wet Houdende Decentralisatie van Het Bestuur in Nederlands Indie berhasil diterima dan diundangkan ke dalam Staatsblad van Het Koninkrijk der Nenderlanden Tahun 1903 dengan Nomor 219. Undang-undang tesebut kemudian diundangkan di Hindia Belanda melalui Indische Staatsblad Nomor 329, yang selanjutnya lebih dikenal dengan sebutan Decentralisatie Wet 1903 (UU Desentralisasi 1903). Berdasarkan UU Desentralisasi 1903, Pemerintah Hindia Belanda dimungkinkan membentuk daerah otonom berikut dewan perwakilan rakyat di daerah otonom tersebut di luar daerah yang sudah ada sebelumnya yang berbentuk swapraja dan desa yang berdasarkan hukum adat. ${ }^{8}$

Berdasarkan sejarah politik Indonesia yang diterapkan, konsep sentralisalasi merupakan warisan dari struktur sentralisasi pemerintah dari zaman penjajahan Belanda. Namun pada era tersebut telah terlihat berbagai upaya untuk mewujudkan struktur desentralisasi yang dimulai sejak disahkannya UndangUndang Desentralisasi 1903 di Hindia Belanda. Undang-Undang ini memiliki tujuan ganda yang dampaknya saling bertentangan yaitu untuk mendesentralisasi pemerintahan di berbagai daerah yang jauh dan sangat beragam sifatnya, serta untuk mengembangkan kontrol pemerintah terhadap berbagai wilayah tersebut. ${ }^{9}$

Sementara, Undang-Undang Nomor 5 Tahun 1974 tentang Pokok-Pokok Pemerintahan di Daerah (UU Pemda 1974) tidak menganut pandangan yang

4 Arief Hidayat dan Adji Samekto, Kajian Kritis Penegakan Hukum Lingkungan di Era Otonomi Daerah, Semarang: Badan Penerbit Universitas Diponegoro, 2007, hlm. 107.

5 Bungaran Antonius Simanjuntak, Iswan, Kaputra (eds.), Dampak Otonomi Daerah di Indonesia, Merangkai Sejarah Politik dan Pemerintahan Indonesia, Cetakan Pertama, Jakarta: Yayasan Pustaka Obor Indonesia, 2013, hlm. 102.

6 Ahmad Yani, Hubungan Keuangan Antara Pemerintah Pusat dan Daerah di Indonesia, Cetakan ke-5, Jakarta: Raja Grafindo Persada, 2013, hlm. 19.

7 Bungaran Antonius Simanjuntak, Loc.cit.

8 S. F. Marbun, Otonomi Daerah 1945-2011: Proses dan Realita Perkembangan Otoda Sejak Jaman Kolonial Sampai Saat ini, Cetakan Kedua, Jakarta: Pustaka Sinar Harapan, 2010, hlm. 30.

9 Internasional IDEA, Penilaian Demokratisasi di Indonesia, Stockholm: Internasinal IDEA, 2000, hlm. 69. 
memiliki dikotomi seperti UU Desentralisasi 1903. Desentralisasi dan dekonsentrasi dipandang sama pentingnya dalam penyelenggaraan pemerintahan di daerah. Tentunya detail dari kebijaksanaan yang non-dikotomi itu masih dapat disempurnakan lebih lanjut, sehingga aneka kontroversi yang dapat menghambat pelaksanaan otonomi daerah yang nyata dan bertanggung jawab dapat dihilangkan. ${ }^{10}$

Perkembangan selanjutnya adalah ditetapkannya Undang-Undang Nomor 22 Tahun 1999 Tentang Pemerintahan Daerah (UU Pemda 1999) dan Undang-Undang Nomor 25 Tahun 1999 Tentang Perimbangan Keuangan antara Pusat dan Daerah (UU Perimbangan Keuangan 1999) sebagai tonggak pemberian wewenang kepada daerah untuk mengelola pemerintahan dan sumber daya alamnya. Hal ini disempurnakan dengan Undang-Undang Nomor 32 tahun 2004 Tentang Pemerintah Daerah (UU Pemda 2004) yang memberikan hak, wewenang, dan kewajiban daerah otonom untuk mengatur dan mengurus sendiri urusan pemerintahan dan kepentingan masyarakat setempat sesuai dengan peraturan perundang-undangan. ${ }^{11}$ Pada Pasal 239 UU Pemda 2004, dinyatakan bahwa dengan berlakunya undang-undang ini, UU Pemda 1999 dinyatakan tidak berlaku lagi.

Pada UU Pemda 2004 diperjelas dan dipertegas hubungan hierarki antara kabupaten dengan provinsi dan provinsi dengan pemerintah pusat berdasarkan asas kesatuan administrasi dan kesatuan wilayah. Dalam UU Pemda 2004 dijelaskan bahwa pemerintah pusat berhak melakukan koordinasi, supervisi, dan evaluasi terhadap pemerintahan di bawahnya, demikian juga pemerintahan provinsi terhadap kabupaten/kota. Di samping itu, hubungan kemitraan dan sejajar antara kepala daerah dan Dewan Perwakilan Rakyat Daerah (DPRD) semakin dipertegas dan diperjelas batasannya.

Perkembangan terakhir terkait undang-undang pemerintahan daerah, ditetapkan dalam rumusan Undang-Undang Nomor 23 Tahun 2014 (UU Pemda 2014) yang memprioritaskan peningkatan efisiensi dan efektivitas penyelenggaraan pemerintahan daerah dengan memperhatikan aspek-aspek hubungan antara pemerintah pusat dengan daerah dan antar daerah, potensi, dan keanekaragaman daerah, serta peluang dan tantangan persaingan global. Sistem penyelenggaraan pemerintahan negara menurut undang-undang ini memberikan peluang pemerintah daerah memimpin pelaksanaan urusan pemerintahan yang menjadi kewenangan daerah otonom (Pasal 1 angka 3). Pemerintahan daerah adalah penyelenggaraan urusan pemerintahan oleh pemerintah daerah dan DPRD menurut asas otonomi dan tugas pembantuan dengan prinsip otonomi seluas-

10 Soewargono Prawirohardjo, Prinsip-Prinsip Pemerintah Umum Dalam Pelaksanaan Pemerintahan di Daerah, Pemerintahan Daerah di Indonesia, Jakarta: Masyarakat IImu Pemerintahan Indonesia (MIPI), 2009, hlm. 211.

11 Pasal 1 angka 5 UU Pemda 2004. 
luasnya dalam sistem dan prinsip NKRI sebagaimana dimaksud dalam UUD 1945 (Pasal 1 angka 2).

Penjelasan di atas menunjukkan bahwa penyerahan dan pelimpahan kewenangan kepada daerah dari waktu ke waktu selalu mengalami dinamika yang mempengaruhi hubungan pusat dan daerah. Dalam beberapa peraturan, daerah diposisikan sebagai wakil pemerintah pusat bukan institusi otonom sebagai penyalur aspirasi masyarakat di daerah. Kewenangan daerah tidak terlepas dari kesatuan kewenangan pemerintah pusat yang diatur secara tegas dalam peraturan perundang-undangan mengenai pendelegasian antara pemerintahan pusat dengan pemerintahan daerah dalam melaksanakan pemerintahan. Implikasi penyerahan dan pelimpahan kewenangan tersebut tidak melepaskan campur tangan pemerintah pusat secara intensif dalam mengawasi pelaksanaan pemerintahan di daerah sebagai prinsip negara kesatuan. ${ }^{12}$ Oleh karena itu, dalam artikel ini akan dibahas tentang pengawasan pelaksanaan pemerintahan daerah oleh pusat khususnya pengawasan yang bersifat preventif yang dimaksudkan untuk mengetahui apakah pengawasan preventif yang diatur dalam UU Pemda 2014 sudah tepat sasaran atau tidak.

\section{B. Esensi Otonomi Daerah di Era Reformasi}

Reformasi merupakan suatu gerakan yang menghendaki adanya perubahan kehidupan bermasyarakat, berbangsa, dan bernegara ke arah yang lebih baik secara konstitusional. Hal ini berarti adanya perubahan kehidupan dalam bidang politik, ekonomi, hukum, sosial, dan budaya yang lebih baik, demokratis berdasarkan prinsip kebebasan, persamaan, dan persaudaraan. Gerakan reformasi lahir sebagai jawaban atas krisis yang melanda berbagai segi kehidupan. Krisis politik, ekonomi, hukum, dan krisis sosial merupakan faktor-faktor yang mendorong lahirnya gerakan reformasi.

Pemerintahan Orde Baru dinilai tidak mampu menciptakan kehidupan masyarakat yang adil dalam kemakmuran dan keadilan berdasarkan Pancasila dan UUD 1945. Oleh karena itu, tujuan lahirnya gerakan reformasi adalah untuk memperbaiki tatanan perikehidupan bermasyarakat, berbangsa, dan bernegara. Kesulitan masyarakat dalam memenuhi kebutuhan pokok merupakan faktor atau penyebab utama lahirnya gerakan reformasi. Reformasi merupakan gerakan moral untuk menjawab ketidakpuasan dan keprihatinan atas kehidupan politik, ekonomi, hukum, dan sosial. Reformasi bertujuan untuk menata kembali kehidupan bermasyarakat, berbangsa, dan bernegara yang lebih baik berdasarkan nilai-nilai luhur Pancasila.

12 Sheldon S. Steinberg dan David T. Austern, Government Ethics and Managers: Penyelewengan Aparat Pemerintah, diterjemahkan oleh Suroso, Bandung: Remaja Rosdakarya, 1999, hlm. 18. 
Pada era reformasi saat ini, pemerintah telah mengeluarkan dua kebijakan tentang otonomi daerah, yaitu UU Pemda 1999 dan UU Perimbangan Keuangan 1999 yang kemudian direvisi oleh UU Pemda 2004 dan Undang-Undang Nomor 33 Tahun 2004 tentang Perimbangan Keuangan Antara Pemerintah Pusat dan Daerah (UU Perimbangan Keuangan 2004). Pada saat ini telah ditetapkan UU Pemda 2014 yang merevisi UU Pemda 2004.

Dasar hukum otonomi daerah adalah Pasal 18 ayat (2) UUD 1945 yang mengamanatkan pemerintahan daerah provinsi, daerah kabupaten dan kota untuk mengatur dan mengurus sendiri urusan pemerintahan menurut asas otonomi dan tugas pembantuan. Penyerahan kewenangan kepada daerah ini tidak lagi membentuk suatu pemerintahan yang bersifat sentralistis, karena dengan bergesernya kewenangan dan dengan penyerahan tugas kepada pemerintah daerah untuk mengatur daerahnya, prinsip desentralisasi ini menjadi sangat penting sehingga akan melahirkan otonomi daerah dan prinsip tugas pembantuan. Desentralisasi dalam arti self goverment menurut Smith dalam Khairul Muluk berkaitan dengan adanya subsidi teritori yang memiliki self goverment melalui lembaga politik yang akan direkrut secara demokratis sesuai dengan yurisdiksinya. ${ }^{13}$

Otonomi daerah menurut ketentuan Pasal 1 angka 5 UU Pemda 2004 adalah hak, wewenang, dan kewajiban daerah otonom untuk mengatur dan mengurus sendiri urusan pemerintahan dan kepentingan masyarakat setempat sesuai dengan peraturan perundang-undangan. Sedangkan otonomi daerah menurut ketentuan Pasal 1 angka 6 UU Pemda 2014 adalah hak, wewenang, dan kewajiban daerah otonom untuk mengatur dan mengurus sendiri urusan pemerintahan dan kepentingan masyarakat setempat dalam sistem NKRI.

Van Der Pot mengartikan otonomi adalah autonomie betekent anders van het eoord sou den vermoeden regeling en bestuur vaqn eigen zaken, van wet dogrountwet noemtegen huishouding (pada dasarnya otonomi itu berarti pengaturan, pengurusan dan penyelenggaraan pemerintahan sendiri. ${ }^{14}$ Konsep otonomi daerah dikenal dalam tiga ajaran, yaitu: $:^{15}$

1. Sistem rumah tangga secara materiil atau materiele huishourdings begrip adalah sistem rumah tangga daerah yang ditentukan sepenuhnya secara rinci (detail) oleh pemerintah pusat berdasarkan peraturan perundang-undangan;

2. Sistem rumah tangga secara formal atau formaele huishourdings begrip adalah sistem rumah tangga daerah yang tidak menentukan secara pasti isi atau macam urusan rumah tangga daerah dalam undang-undang; dan

3. Sistem rumah tangga riil atau riele huishourdings begrip. Sistem ini lebih lentur dan cukup fleksibel dengan tidak mengurangi kepastian hukum.

\footnotetext{
13 Kharul Muluk, Desentralisasi dan Pemerintahan Daerah, Malang: Bayumedia Publishing, 2005, hlm. 8.

${ }^{14}$ Suko Wiyono, Otonomi Daerah Dalam Negara Hukum Indonesia, Jakarta: Faza Media, hlm. 49.

15 Ibid.
} 


\section{Ruang Lingkup Pengawasan Pemerintah Pusat Terhadap Daerah}

Dasar hubungan antara pusat dan daerah adalah bahwa pemerintah pusat menyerahkan sebagian wewenang pemerintahannya kepada daerah untuk diatur dan diurus sendiri sebagai urusan rumah tangga daerah (otonom). ${ }^{16}$ Agar wewenang yang telah diserahkan oleh pusat kepada daerah tidak disalahgunakan, digunakanlah instrumen pengawasan. Pengawasan dalam Hukum Administrasi Negara (HAN) bermakna mencegah timbulnya segala bentuk penyimpangan tugas pemerintahan dari hal-hal yang telah diberikan (preventif) dan menindak atau memperbaiki penyimpangan yang terjadi (represif). ${ }^{17}$ Pengertian pengawasan oleh Bagir Manan, yaitu:

Pengawasan (toezicht, supervision) adalah suatu bentuk hubungan dengan legal entity yang mandiri, bukan hubungan internal dari entitas yang sama. Bentuk dan isi pengawasan dilakukan semata-mata menurut atau berdasarkan ketentuan undang-undang. Hubungan pengawasan hanya dilakukan terhadap hal yang secara tegas ditentukan dalam undangundang. Pengawasan tidak berlaku atau tidak diterapkan terhadap hal yang tidak ditentukan atau berdasarkan undang-undang. ${ }^{18}$

Secara umum, pengawasan adalah salah satu fungsi manajemen kontrol yang selanjutnya disebut pengawasan dalam arti luas. ${ }^{19}$ Pengawasan disebut dengan 'controlling' yang juga berarti fungsi pengendalian. Pengawasan adalah segala sesuatu atau kegiatan untuk mengetahui dan menilai kenyataan yang sebenarnya tentang pelayanan tugas atau pekerjaan apakah sesuai dengan semestinya atau tidak. Pengawasan ini dapat dibedakan atas pengawasan yang bersifat intern dan ekstern.

Pengawasan intern diartikan bahwa pengawasan dilakukan oleh suatu badan yang secara organisatoris atau struktural masih termasuk dalam lingkungan pemerintah itu sendiri. Bentuk kontrol semacam ini dapat digolongkan dalam jenis teknis-administratif atau built-in control. Jenis pengawasan yang kedua adalah kontrol yang bersifat eksternal yaitu kontrol yang dilakukan secara tidak langsung melalui badan-badan peradilan (judicial control) ketika terjadi suatu sengketa atau perkara yang menyangkut pihak pemerintah. Pengawasan juga dapat dibedakan dari dua sisi yaitu pengawasan dari sisi pelaksanaan dan pengawasan dari sisi objek. ${ }^{20}$

\footnotetext{
${ }^{16}$ Widodo Ekathahjana, Pengujian Peraturan Perundang-undangan dan Sistem Peradilannya di Indonesia, Jakarta: Pustaka Sutra, 2008, hlm. 39.

17 S.F.Marbun, dkk, Dimensi-Dimensi Hukum Administrasi Negara, Yogyakarta: UII Press, 2004, hlm. 267.

18 Jazim Hamidi dan Mustafa Lutfi, Dekonstruksi Hukum Pengawasan Pemerintahan Daerah, Malang: UB Press, 2011, hlm. 42.

19 Suyamto, Beberapa Aspek Pengawasan di Indonesia, Jakarta: Sinar Grafika, hlm. 7.

20 Widodo Ekathahjana, Op.cit., hlm. 41.
} 
Pengendalian merupakan segala usaha atau kegiatan untuk menjamin dan mengarahkan agar pelaksanaan tugas atau pekerjaan sesuai dengan semestinya. Perbedaannya terletak pada kewenangan untuk melakukan tindakan korektif dan pendelegasian kewenangan. Ketika dilakukan suatu pengendalian akan disertai dengan kewenangan tindakan korektif, sementara dalam pelaksanaan suatu pengawasan, tidak ada kewenangan melakukan tindakan korektif. ${ }^{21}$ Dengan demikian, pengendalian mempunyai lingkup yang lebih luas dari pengawasan yang mencakup: ${ }^{22}$

1. pengawasan, baik preventif maupun represif;

2. petunjuk pengarahan/instruksi dari pimpinan;

3. peninjauan dari pengamatan secara langsung di tempat kegiatan;

4. menghimpun dan menganalisis semua informasi yang berhubungan dengan kegiatan proyek yang bersangkutan; dan

5. menentukan kebijakan lebih lanjut.

Bagir Manan menyatakan terdapat dua model pengawasan terkait pemerintahan otonomi, yaitu pengawasan preventif (preventief toezicht) dan pengawasan represif (repressief toezicht). ${ }^{23}$ Kedua model pengawasan ini ditujukan pada produk hukum yang dihasilkan daerah, dan pengawasan terhadap tindakan tertentu dari organ pemerintahan daerah yang dilakukan melalui wewenang mengesahkan (goedkeuring) dalam pengawasan preventif maupun wewenang pembatalan (vernietiging) atau penangguhan (schorsing) dalam pengawasan represif.

Apabila model pengawasan di atas dikaitkan dengan implementasi pengawasan peraturan daerah sebagai salah satu produk penyelenggaraan pemerintahan otonomi, maka model pengawasan preventif ini dilakukan dengan pemberian pengesahan atau penolakan pengesahan peraturan daerah (perda) yang disusun oleh pemerintahan daerah (pemda). Pengawasan yang dilakukan oleh pemerintah pusat kepada daerah merupakan pengawasan internal yang hanya berada pada ranah eksekutif saja. Dalam pengawasan preventif, perda yang dihasilkan hanya dapat berlaku apabila telah terlebih dahulu disahkan oleh penguasa yang berwenang mengesahkan. Model pengawasan preventif ini pada prinsipnya hanya dilakukan terhadap perda yang mengatur sejumlah materi-materi tertentu yang ditetapkan sebelumnya melalui peraturan perundang-undangan.

Pengawasan represif dilaksanakan dalam dua bentuk, yaitu menangguhkan berlakunya suatu perda atau membatalkan suatu perda. Model pengawasan represif ini dapat dijalankan terhadap semua peraturan daerah yang dianggap

\footnotetext{
21 Ibid.

22 Rawan Soejito, Hubungan Pemerintah Pusat dan Pemerintah Daerah, Jakarta: Rineka Cipta, 1990.

${ }^{23}$ Widodo Ekathahjana, Op.cit., hlm. 43.
} 
bertentangan dengan peraturan perundang-undangan yang lebih tinggi tingkatannya atau bertentangan dengan kepentingan umum. Khusus untuk penangguhan, sebenarnya instrumen ini merupakan suatu usaha persiapan dari proses pembatalan, terdapat suatu penangguhan aturan yang terjadi karena sedang dilakukan pertimbangan untuk membatalkan perda dimaksud. Namun demikian, tidak semua pembatalan harus melalui proses penangguhan, karena dimungkinkan pejabat yang memiliki kewenangan ini dapat langsung membatalkan perda yang dianggap bertentangan dengan peraturan perundang-undangan yang lebih tinggi tingkatannya atau bertentangan dengan kepentingan umum.

\section{Pengawasan Preventif Sebagai Kontrol Pusat Terhadap Daerah di Era Otonomi}

Sesuai dengan penjelasan di atas, otonomi daerah adalah hak, wewenang, dan kewajiban daerah otonom untuk mengatur dan mengurus sendiri urusan pemerintahan dan kepentingan masyarakat setempat dalam sistem NKRI. Agar kebijakan daerah dan penyelenggaraan kekuasaan daerah dapat memenuhi rasa keadilan, kebutuhan dan keadilan masyarakat setempat, pelaksanaan otonomi harus memenuhi persyaratan sebagai berikut: ${ }^{25}$

1. Otonomi bukan hanya menyangkut penyelenggaraan kekuasaan pemerintah ataupun legislatif, tetapi yang lebih penting lagi adalah perwujudan kedaulatan rakyat. Oleh karena itu, pengalihan kekuasaan dari pemerintahan pusat harus menjadi bagian dari proses demokrasi yang dicirikan oleh adanya pengembangan kemampuan dan sistem pertanggungjawaban baik secara politik maupun hukum, secara terbuka oleh pejabat daerah serta pengembangan kemampuan dan peluang rakyat setempat dalam melakukan pengawasan;

2. Otonomi yang paling dasar haruslah ada pada tingkat komunitas masyarakat terkecil seperti desa atau sejenisnya;

3. Agar otonomi terhindar dari sistem negara di dalam negara, pengelolaan daerah-daerah otonom harus dilandaskan baik pada konstitusi nasional maupun pada peraturan perundang-undangan lainnya yang berlaku secara nasional dan universal;

4. Oleh karena itu otonomi memerlukan masyarakat sipil yang terdiri dari unsur yang ada di dalam masyarakat, yang kuat, solid, selalu berpikir kritis dan mampu malakukan kontrol atau pengawasan terhadap penyelenggaraan kekuasaan daerah yang berada di tangan eksekutif, legislatif dan yudikatif;

\footnotetext{
24 Ibid.

${ }^{25}$ Laporan Hasil Penelitian, Otonomi Daerah dan Pengelolaan Sumber Daya Alam Fakultas Hukum Universitas Diponegoro, dalam Irene Mariane, Kearifan Lokal Pengelolaan Hutan Adat, Jakarta: Raja Grafindo Persada, 2014, hlm. 286.
} 
5. Otonomi haruslah merubah pandangan dan perilaku penyelenggara kekuasaan di daerah untuk benar-benar menjadi pelayan masyarakat, artinya kepentingan masyarakat harus menjadi pijakan bagi pembuatan kebijakan daerah;

Hubungan antara pemerintah pusat dengan pemerintah daerah di Indonesia menerapkan pola hubungan desentralistis sesuai dengan UUD 1945. Hubungan ini mengandung arti bahwa hubungan antara pemerintah pusat dan daerah merupakan hubungan antara dua badan hukum yang diatur dalam undang-undang tentang desentralisasi, tidak semata-mata hubungan antara bawahan dengan atasan. Dengan demikian, pengawasan terhadap pemerintahan daerah dalam sistem pemerintahan di Indonesia lebih ditujukan untuk memperkuat ekonomi daerah, bukan untuk mengekang ataupun membatasi kewenangan.

Pengawasan terhadap segala tindakan pemerintah daerah oleh pemerintah pusat, termasuk keputusan kepala daerah dan perda, telah dilaksanakan sejak otonomi daerah diberlakukan pertama kali (UU Nomor 1 Tahun 1945 tentang Peraturan Mengenai Kedudukan Komite Nasional Daerah) sampai saat ini (UU Pemda 2014). Dalam UU Pemda 2014, ada dua kategori pengawasan, yaitu:

\section{Pasal 377}

Ayat (1) Yang dimaksud dengan 'pengawasan umum' adalah pengawasan terhadap pembagian Urusan Pemerintahan yang menjadi kewenangan Daerah provinsi, kelembagaan Daerah provinsi, kepegawaian pada Perangkat Daerah provinsi, keuangan Daerah provinsi, pembangunan Daerah provinsi, pelayanan publik di Daerah provinsi, kerja sama Daerah provinsi, kebijakan Daerah provinsi, Gubernur dan DPRD provinsi, dan bentuk pembinaan lain sesuai dengan ketentuan peraturan perundangundangan.

Ayat (2) Yang dimaksud dengan 'pengawasan teknis' adalah pengawasan terhadap teknis pelaksanaan substansi Urusan Pemerintahan yang diserahkan kepada Daerah provinsi sesuai dengan kewenangan kementerian/lembaga pemerintah nonkementerian masing-masing.

\section{Pasal 378}

Ayat (1) Yang dimaksud dengan 'pengawasan umum' adalah pengawasan terhadap pembagian Urusan Pemerintahan yang menjadi kewenangan Daerah kabupaten/kota, kelembagaan Daerah kabupaten/kota, kepegawaian pada Perangkat Daerah kabupaten/kota, keuangan Daerah kabupaten/kota, pembangunan Daerah kabupaten/kota, pelayanan publik di Daerah kabupaten/kota, kerja sama Daerah kabupaten/kota, kebijakan Daerah kabupaten/kota, bupati/walikota dan DPRD kabupaten/kota, dan bentuk pembinaan lain sesuai dengan ketentuan peraturan perundang- 
undangan. Yang dimaksud dengan 'pengawasan teknis' adalah pengawasan terhadap teknis pelaksanaan substansi Urusan Pemerintahan yang diserahkan kepada Daerah kabupaten/kota.

\section{Pasal 379}

Ayat (2) Khusus untuk pengawasan yang terkait keuangan Daerah meliputi kegiatan audit, reviu, evaluasi, pemantauan, dan bimbingan teknis dalam pengelolaan APBD provinsi yaitu sejak tahap perencanaan, pelaksanaan, pemantuan dan evaluasi atas pelaksanaan APBD (termasuk penyerapan APBD), sampai dengan pertanggungjawaban pelaksanaan APBD provinsi yang dilakukan oleh inspektorat provinsi dapat bekerja sama dengan inspektorat jenderal Kementerian dan/atau lembaga pemerintah nonkementerian yang menyelenggarakan urusan pemerintahan bidang pengawasan.

\section{Pasal 380}

Ayat (2) Khusus untuk pengawasan yang terkait keuangan Daerah meliputi kegiatan audit, reviu, evaluasi, pemantauan, dan bimbingan teknis dalam pengelolaan APBD kabupaten/kota yaitu sejak tahap perencanaan, pelaksanaan, pemantuan dan evaluasi atas pelaksanaan APBD (termasuk penyerapan APBD), sampai dengan pertanggungjawaban pelaksanaan APBD kabupaten/kota yang dilakukan inspektorat kabupaten/kota dapat bekerja sama dengan Inspektorat Jenderal Kementerian dan/atau lembaga pemerintah nonkementerian yang menyelenggarakan urusan pemerintahan bidang pengawasan.

Dalam konteks penyelenggaraan pemerintahan daerah maka pengawasan harus disertai pembatasan-pembatasan. ${ }^{26}$ Semakin ketat pengawasan, maka semakin kecil otonomi daerah, dan berlaku pula sebaliknya. Bagaimanapun juga, dalam sistem unitary, pemerintahan daerah bukanlah negara bagian yang mempunyai kedaulatan sendiri sebagaimana dalam sistem federal, namun pemerintahan daerah adalah subsistem pemerintahan pusat (nasional). Oleh karena itu pemerintahan daerah bersifat dependent dan subordinate terhadap pemerintahan pusat yang mempunyai kewenangan melakukan pembinaan dan pengawasan terhadap pemerintahan daerah, agar dalam penyelenggaraan pemerintahan tidak menyimpang dari sistem pemerintahan pusat, tidak melakukan tindakan yang bertentangan dengan kebijakan pemerintah pusat, dan tidak membuat kebijakan yang bertendensi pada keinginan memisahkan diri dari NKRI. Dengan adanya pembinaan dan pengawasan oleh pemerintah pusat, pemerintah daerah dapat

\footnotetext{
${ }^{26}$ King Faisak Sulaiman, Dialektika Pengujian Peraturan Daerah Pasca Otonomi Daerah, Yogyakarta: Pustaka Pelajar, 2014, hlm. 46.
} 
menyelenggarakan pemerintahannya sendiri sesuai dengan koridor konstitusi dan undang-undang dalam sistem pemerintahan nasional dan dapat mencapai tujuan negara pada tingkat daerah secara efektif dan efisien.

Pembatasan dalam pengawasan kewenangan daerah mencakup pula pembatasan macam atau bentuk pengawasan. Suatu pengawasan akan memiliki fungsi kontrol apriori ketika pengawasan tersebut dilakukan sebelum keluarnya suatu keputusan atau ketetapan pemerintah daerah. Disini tampak jelas unsur preventif kontrol tersebut memiliki tujuan utama berupa pencegahan terjadinya suatu kesalahan dalam praktik pengambilan keputusan. ${ }^{27}$

Pada sisi lain, ada pendapat yang mengatakan bahwa sistem pengawasan terhadap pemerintah dalam konteks pengertian umum masih tetap relevan. Hal ini disebabkan karena beberapa alasan, yaitu:

1. Pada umumnya sasaran pengawasan terhadap pemerintah adalah pemeliharaan dan penjagaan agar negara hukum kesejahteraan dapat berjalan dengan baik dan dapatmembawa kekuasaan pemerintah sebagai penyelenggara kesejahteraan masyarakat kepada pelaksanaan yang baik pula dan tetap dalam batas kekuasaannya;

2. Tolak ukurnya adalah hukum yang mengatur dan membatasi kekuasaan dan tindakan pemerintah dalam bentuk hukum meteriil maupun hukum formil serta manfaatnya bagi kesejahteraan rakyat;

3. Adanya penyesuaian antara perbuatan dan tolak ukur yang telah ditetapkan;

4. Jika terdapat tanda-tanda akan terjadi penyimpangan terhadap tolak ukur tersebut dilakukan tindakan pencegahan;

5. Apabila dalam penyesuaian menunjukkan terjadinya penyimpangan dari tolak ukur. Kemudian koreksi melalui tindakan pembatalan, dan pemulihan terhadap akibat yang ditimbulkan dan mendisiplinkan pelaku kekeliruan. ${ }^{28}$

Perubahan sistem pengawasan dari UU Pemda 2004 ke UU Pemda 2014 terlihat dari model pengawasan terhadap produk hukum daerah yang terbatas pada pengawasan yang tergolong pengawasan preventif, yaitu: ${ }^{29}$

\begin{tabular}{|c|c|c|c|}
\hline No. & $\begin{array}{c}\text { Model } \\
\text { Pengawasan }\end{array}$ & UU Pemda 2004 & UU Pemda 2014 \\
\hline 1. & Executive preview & $\begin{array}{l}\text { Pasal } 185 \text { ayat } 1 \\
\text { Rancangan Perda provinsi tentang } \\
\text { APBD yang telah disetujui bersama } \\
\text { dan rancangan Peraturan Gubernur }\end{array}$ & $\begin{array}{l}\text { Pasal } 245 \text { ayat } 1 \\
\text { Rancangan Perda Provinsi yang } \\
\text { mengatur tentang RPJPD, RPJMD, APBD, } \\
\text { perubahan APBD, pertanggungjawaban }\end{array}$ \\
\hline
\end{tabular}

27 Ibid.

${ }^{28} \mathrm{Ibid} ., \mathrm{hlm} .47$.

${ }^{29}$ Ni'matul Huda, “Hubungan Pengawasan Produk Hukum Daerah antara Pemerintah dengan Pemerintah Daerah dalam Negara Kesatuan Republik Indonesia", Jurnal Hukum, Edisi Khusus, Volume 16, Oktober 2009. 


\begin{tabular}{|c|c|c|c|}
\hline & & $\begin{array}{l}\text { tentang penjabaran APBD sebelum } \\
\text { ditetapkan oleh Gubernur paling } \\
\text { lambat } 3 \text { (tiga) hari disampaikan } \\
\text { kepada Menteri Dalam Negeri untuk } \\
\text { dievaluasi. } \\
\text { Pasal186(1) } \\
\text { Rancangan Perda kabupaten/kota } \\
\text { tentang APBD yang telah disetujui } \\
\text { bersama dan rancangan Peraturan } \\
\text { Bupati/Walikota tentang Penjabaran } \\
\text { APBD sebelum ditetapkan oleh } \\
\text { Bupati/Walikota paling lama } 3 \text { (tiga) } \\
\text { hari disampaikan kepada Gubernur } \\
\text { untuk dievaluasi. }\end{array}$ & $\begin{array}{l}\text { pelaksanaan APBD, pajak daerah, } \\
\text { retribusi daerah dan tata ruang daerah } \\
\text { harus mendapat evaluasi Menteri } \\
\text { sebelum ditetapkan oleh gubernur. } \\
\text { Pasal } 245 \text { ayat } 3 \\
\text { Rancangan Perda kabupaten/kota yang } \\
\text { mengatur tentang RPJPD, RPJMD, APBD, } \\
\text { perubahan APBD, pertanggungjawaban } \\
\text { pelaksanaan APBD, pajak daerah, } \\
\text { retribusi daerah, dan tata ruang daerah } \\
\text { harus mendapat evaluasi gubernur } \\
\text { sebagai wakil Pemerintah Pusat sebelum } \\
\text { ditetapkanoleh bupati/wali kota. }\end{array}$ \\
\hline 2. & Executive review & $\begin{array}{l}\text { Pasal } 185 \text { ayat } 5 \\
\text { Apabila hasil evaluasi tidak } \\
\text { ditindaklanjuti oleh Gubernur dan } \\
\text { DPRD, dan G ubernur tetap } \\
\text { menetapkan rancangan Perda tentang } \\
\text { APBD dan rancangan Peraturan } \\
\text { Gubernur tentang penjabaran APBD } \\
\text { menjadi Perda dan Peraturan } \\
\text { Gubernur, Menteri Dalam Negeri } \\
\text { rnembatalkan Perda dan Peraturan } \\
\text { Gubernur dimaksud sekaligus } \\
\text { menyatakan berlakunya pagu APBD } \\
\text { tahunsebelumnya. } \\
\text { Pasal186ayat5 } \\
\text { Apabila hasil evaluasi tidak } \\
\text { ditindaklanjuti oleh Bupati/Walikota } \\
\text { dan DPRD, dan Bupati/Walikota tetap } \\
\text { menetapkan rancangan Perda tentang } \\
\text { APBD dan rancangan Peraturan } \\
\text { Bupati/Walikota tentang penjabaran } \\
\text { APBD menjadi Perda dan Peraturan } \\
\text { B upati / Walikota, Gubernu r } \\
\text { membatalkan Perda dan Peraturan } \\
\text { Bupati/Walikota dimaksud sekaligus } \\
\text { menyatakan berlakunya pagu APBD } \\
\text { tahunsebelumnya. }\end{array}$ & $\begin{array}{l}\text { Pasal } 268 \text { ayat } 4 \\
\text { A pa bila ha sil evaluasi tidak } \\
\text { ditindaklanjuti oleh gubernur dan DPRD } \\
\text { serta gubernur menetapkan rancangan } \\
\text { Perda Provinsi tentang RPJPD menjadi } \\
\text { Perda, Menteri membatalkan Perda } \\
\text { dimaksud. } \\
\text { Pasal } 269 \text { ayat } 4 \\
\text { Dala m hal hasil evaluasi tidak } \\
\text { ditindaklanjuti oleh gubernur dan DPRD } \\
\text { dan gubernur menetapkan rancangan } \\
\text { Perda Provinsi tentang RPJMD menjadi } \\
\text { Perda, Menteri membatalkan Perda } \\
\text { dimaksud. } \\
\text { Pasal } 270 \text { ayat } 4 \\
\text { Dalam hal hasil evaluasi tidak } \\
\text { ditindaklanjuti oleh bupati/wali kota dan } \\
\text { DPRD kabupaten/kota, dan bupati/wali } \\
\text { kota menetapkan rancangan Perda } \\
\text { Kabupaten/Kota tentang RPJPD menjadi } \\
\text { Perda, gubernur sebagai wakil } \\
\text { Pemerintah Pusat membatalkan Perda } \\
\text { dimaksud. } \\
\text { Pasal } 271 \text { ayat } 4 \\
\text { Dala m hal hasil evaluasi tidak } \\
\text { ditindaklanjuti oleh bupati/wali kota dan } \\
\text { DPRD kabupaten/kota dan bupati/wali } \\
\text { kota menetapkan rancangan Perda } \\
\text { Kabupaten/Kota tentang RPJMD } \\
\text { kabupaten/kota menjadi Perda, } \\
\text { gubernur sebagai wakil Pemerintah Pusat } \\
\text { membatalkan Perda dimaksud. }\end{array}$ \\
\hline
\end{tabular}




\begin{tabular}{|c|c|c|c|}
\hline 3. & $\begin{array}{l}\text { Pengawasan } \\
\text { Preventif }\end{array}$ & $\begin{array}{l}\text { Pasal } 185 \text { ayat } 5 \\
\text { Apabila Menteri Dalam Negeri } \\
\text { menyatakan hasil evaluasi rancangan } \\
\text { Perda tentang APBD dan rancangan } \\
\text { Peraturan Gubernur tentang } \\
\text { penjabaran APBD sudah sesuai dengan } \\
\text { kepantingan. Umum dan peraturan } \\
\text { Perundang-undangan yang lebih } \\
\text { tinggi, Gubernur menetapkan } \\
\text { rancangan dimaksud menjadi Perda } \\
\text { dan Peraturan Gubernur. } \\
\text { Pasal } 186 \text { ayat3 } \\
\text { Apabila Gubernur menyatakan hasil } \\
\text { evaluasi rancangan Perda tentang } \\
\text { APBD dan rancangan Peraturan } \\
\text { Bupati/Walikota tentang Penjabaran } \\
\text { APBD sudah se suai dengan } \\
\text { kepentingan umum dan peraturan } \\
\text { perundang-undangan yang lebih } \\
\text { tinggi, Bupati/Walikota menetapkan } \\
\text { rancangan dimaksud menjadi Perda } \\
\text { danPeraturan Bupati/Walikota. }\end{array}$ & $\begin{array}{l}\text { Pasal } 245 \text { ayat } 5 \\
\text { Hasil evaluasi rancangan Perda Provinsi } \\
\text { dan rancangan Perda Kabupaten/Kota } \\
\text { sebagaimana dimaksud pada ayat (1) dan } \\
\text { ayat (3) jika disetujui diikuti dengan } \\
\text { pemberian nomor register. } \\
\text { Pasal } 243 \\
\text { (1) Rancangan Perda yang belum } \\
\text { me } n \text { da pat ka n no mor re giste r } \\
\text { sebagaimana dimaksud dalam Pasal } 242 \\
\text { ayat (5) belum dapat ditetapkan kepala } \\
\text { Daerah dan belum dapat diundangkan } \\
\text { dalam lembaran daerah. }\end{array}$ \\
\hline
\end{tabular}

Dari berbagai ketentuan yang diatur dalam berbagai pasal di atas, maka dapat dipahami bahwa pengawasan preventif yang diterapkan oleh UU Pemda 2004 dapat dirumuskan, pengawasan preventif khusus dilakukan untuk Perda yang menyangkut pajak daerah, retribusi dan tata ruang (RUTR). Berbeda dengan UU Pemda 2014 yang model pengawasan preventif terhadap produk hukum daerah, tidak memiliki perbedaan yang signifikan. Hanya istilah saja yang berbeda yaitu penambahan istilah pemberian nomor registrasi pada rancangan perda provinsi dan rancangan perda kabupaten/kota menurut UU Pemda 2014.

Melalui kedua undang-undang tersebut, menjadi sangat jelas bahwa terdapat suatu perubahan yang signifikan dan mengindikasikan fungsi resentralisasi pada hubungan kewenangan antara pemerintah pusat dengan daerah, karena bagaimanapun penerapan dari hubungan antar pemerintah tersebut adalah melalui produk hukum daerah yang dirumuskan dalam bentuk perda. Perda merupakan produk hukum yang dibentuk oleh pemda. Perda provinsi dibentuk oleh gubernur bersama-sama dengan DPRD provinsi, perda kabupaten/kota dibentuk oleh bupati/walikota bersama-sama dengan DPRD kabupaten/kota. Perda sebagai produk hukum daerah merupakan bentuk hukum yang tertulis yang berisi aturan tingkah laku yang bersifat mengikat secara umum. Substansi perda harus mencerminkan suatu pelaksanaan dari segala peraturan perundang-undangan yang lebih tinggi tingkatannya dengan memperhatikan kekhususan masing-masing 
daerah dan tidak bertentangan dengan peraturan perundang-undangan yang lebih tinggi dan dirumuskan dengan turut serta mempertimbangkan kepentingan umum. Dalam masyarakat daerah, perda dibentuk dengan tujuan mengatur masyarakat daerah secara umum, agar dapat berperilaku sesuai dengan apa yang diharapkan dan dapat mendukung penyelenggaraan pemerintahan dan pembangunan yang dibentuk sebagai tindak lanjut dari pelaksanaan desentralisasi.

\section{Kewenangan Pusat dan Daerah (Pasal 16, 17, 18 UU Perda 2014)}

\begin{tabular}{|c|c|}
\hline Pemerintah Pusat & Pemerintah Daerah \\
\hline $\begin{array}{l}\text { 1. Menetapkan NSPK, paling lama } 2 \text { (dua) tahun } \\
\text { terhitung sejak peraturan pemerintah mengenai } \\
\text { pelaksanaan urusan pemerintahan konkuren } \\
\text { diundangkan serta melaksanakan pembinaan dan } \\
\text { pengawasan; } \\
\text { 2. Membatalkan kebijakan Daerah yang tidak } \\
\text { berpedoman pada NSPK; } \\
\text { 3. Menetapkan Standar Pelayanan Masyarakat. }\end{array}$ & $\begin{array}{l}\text { 1. Menetapkan kebijakan Daerah untuk } \\
\text { menyelenggarakan Urusan Pemerintahan yang } \\
\text { menjadi kewenangan Daerah berpedoman pada } \\
\text { NSPK; } \\
\text { 2. Dalam jangka waktu } 2 \text { (dua) tahun, Pusat belum } \\
\text { menetapkan NSPK, Pemda melaksanakan Urusan } \\
\text { Pemerintahan yang menjadikewenangan Daerah; } \\
\text { 3. Memprioritaskan pelaksanaan Urusan } \\
\text { Pemerintahan Wajib yang berkaitan dengan } \\
\text { Pelayanan Dasar berpedoman pada Standar } \\
\text { Pelayanan Masyarakat. }\end{array}$ \\
\hline
\end{tabular}

Beberapa pengaturan mengenai hubungan kewenangan antara pusat dan daerah antara lain indikasinya dipertegas pada beberapa Pasal berikut ini:

1. Pada Pasal 9 ayat (4) UU Pemda 2014, ditentukan urusan pemerintahan konkuren yang diserahkan ke daerah menjadi dasar pelaksanaan otonomi daerah. Pada Pasal 9 ayat (3), urusan pemerintahan konkuren sebagaimana dimaksud pada ayat (1) adalah urusan Pemerintahan yang dibagi antara pemerintah pusat dan daerah provinsi dan daerah kabupaten/kota;

2. Pada Pasal 16 (1) pada UU Pemda 2014, pemerintah pusat dalam menyelenggarakan urusan pemerintahan konkuren sebagaimana dimaksud dalam Pasal 9 ayat (3) berwenang untuk:

a. menetapkan norma, standar, prosedur, dan kriteria dalam rangka penyelenggaraan urusan pemerintahan; dan

b. melaksanakan pembinaan dan pengawasan terhadap penyelenggaraan urusan pemerintahan yang menjadi kewenangan daerah. (2) Norma, standar, prosedur, dan kriteria sebagaimana dimaksud pada ayat (1) huruf a berupa ketentuan peraturan perundang-undangan yang ditetapkan oleh pemerintah pusat sebagai pedoman dalam penyelenggaraan urusan pemerintahan konkuren yang menjadi kewenangan pemerintah pusat dan yang menjadi kewenangan daerah.

3. Pasal 17 ayat (2) pada UU Pemda 2014, daerah dalam menetapkan kebijakan daerah sebagaimana dimaksud pada ayat (1), wajib berpedoman pada norma, 
standar, prosedur, dan kriteria yang telah ditetapkan oleh pemerintah pusat. Dalam hal kebijakan daerah yang dibuat dalam rangka penyelenggaraan urusan pemerintahan yang menjadi kewenangan daerah tidak mempedomani norma, standar, prosedur, dan kriteria sebagaimana dimaksud pada ayat (2), pemerintah pusat membatalkan kebijakan daerah sebagaimana dimaksud pada ayat (1);

4. Dalam Penjelasan Pasal 17 pada UU Pemda 2014, yang dimaksud dengan 'kebijakan daerah' adalah perda, perkada, dan keputusan kepala daerah.

Sistem pengawasan juga menentukan kemandirian suatu otonomi yang berada dalam ruang lingkupnya. Untuk menghindari agar pengawasan tidak melemahkan fungsi otonomi, maka sistem pengawasan ditentukan secara spesifik baik lingkup maupun tata cara pelaksanaannya. Oleh sebab itu, pemberlakukan prinsip-prinsip penting seperti 'pengawasan umum' pada satuan otonomi dapat mempengaruhi dan membatasi kemandirian daerah. Dapat dikatakan, semakin banyak dan intensif pengawasan, maka akan berdampak pada makin sempitnya kemandirian yang menyebabkan semakin terbatasnya suatu otonomi. Sebaliknya, tidak boleh ada sistem otonomi yang sama sekali meniadakan pengawasan. Kebebasan berotonomi dan pengawasan merupakan dua sisi dari satu lembaran dalam pelaksanaan otonomi untuk menjaga keseimbangan antara kecenderungan desentralisasi dan sentralisasi yang dapat berlaku berlebihan. ${ }^{30}$ Untuk itu, pengawasan harus disertai pembatasan-pembatasan kewenangan. Pembatasan-pembatasan tersebut akan mencakup pembatasan macam atau bentuk pengawasan yang sekaligus mengandung pembatasan tata cara menyelenggarakan pengawasan, dan pejabat atau badan yang berwenang melakukan pengawasan. Pada umumnya, pengawasan terhadap segala kegiatan pemda termasuk pembuatan perda dan keputusan kepala daerah merupakan suatu akibat mutlak dari adanya negara kesatuan. Di dalam kerangka negara kesatuan, tidak dikenal bagian yang lepas dari atau sejajar dengan negara, tidak mungkin pula adanya suatu negara di dalam negara. ${ }^{31}$

Hasil penelitian menunjukkan bahwa dengan hanya menekankan pada pengawasan represif ternyata mengandung dampak negatif yaitu menimbulkan banyak kerugian bagi masyarakat selain kurang terjaminnya kepastian hukum. Hal ini terbukti dengan banyaknya perda yang dikembalikan dan dibatalkan oleh pemerintah pusat karena dinilai telah merugikan masyarakat. ${ }^{32}$

Dinamika pengawasan dan pengujian atas perda bisa ditinjau pada tabel di bawah ini:33

${ }^{30}$ Bagir Manan, Menyongsong Fajar Otonomi Daerah, Yogyakarta: Pusat Studi Hukum Fakultas Hukum UII, 2004, hlm. 39.

31 Ni'Matul Huda, Op.Cit., hlm. 5.

32 I Wayan Parsa, Pengawasan Pemerintah (Pusat) Dalam Penyelenggaraan Pemerintahan Daerah, Surabaya: Universitas Airlangga, 2005.

${ }^{33}$ King Faisal Sulaiman, Op.Cit., hlm. 11. 


\begin{tabular}{|l|c|c|}
\hline $\begin{array}{c}\text { Pengujian Perda/Raperda } \\
\text { oleh Pemerintah }\end{array}$ & $\begin{array}{c}\text { Departemen Dalam Negeri } \\
\text { (Per Akhir Agustus 2008) }\end{array}$ & $\begin{array}{c}\text { Departemen Keuangan RI } \\
\text { (Per Akhir Desember 2008) }\end{array}$ \\
\hline $\begin{array}{l}\text { Total perda yang setor untuk } \\
\text { di klarifikasi oleh pemerintah }\end{array}$ & 10.503 perda & 8.129 perda \\
\hline $\begin{array}{l}\text { Perda yang diklarifikasi oleh } \\
\text { pemerintah }\end{array}$ & 7.224 perda & 8.219 perda \\
\hline $\begin{array}{l}\text { Perda yang disetujui oleh } \\
\text { pemerintah untuk tetap } \\
\text { berlaku }\end{array}$ & 5.207 perda & 5.450 perda \\
\hline $\begin{array}{l}\text { Perda yang dibatalkan oleh } \\
\text { pemerintah } \\
\text { bermasalah } \\
\begin{array}{l}\text { Total raperda yang disetor } \\
\text { untuk dievalauasi } \text { oleh } \\
\text { pemerintah }\end{array} \\
\begin{array}{l}\text { Raperda yang dievaluasi oleh } \\
\text { pemerintah }\end{array}\end{array}$ & 2.779 perda \\
\hline $\begin{array}{l}\text { Jumlah raperda yang disetujui } \\
\text { oleh pemerintah karena tidak } \\
\text { bermasalah }\end{array}$ & 1.868 perda & 2.257 perda \\
\hline $\begin{array}{l}\text { Jumlah raperda yang } \\
\text { dibatalkan oleh pemerintah } \\
\text { karena bermasalah }\end{array}$ & 2.192 perda \\
\hline
\end{tabular}

Pengawasan yang terlalu ketat dilakukan pemerintah pusat tentunya dapat mengurangi kebebasan dalam konteks pelaksanaan otonomi. Pemda akan merasa terbelenggu dan terbatasinya ruang kerja desentralisasi untuk bekerja secara optimal memberdayakan para pemangku kepentingan di daerah dalam mengelola potensi melayani dan memenuhi kebutuhan masyarakat. Disisi lain, bila pengawasan tidak dilakukan secara tepat dan proporsional oleh pemerintah pusat, daerah dapat bergerak melebihi batas kewenangannya sehingga berpotensi mengancam tata pemerintahan dalam bingkai sistem negara kesatuan. Untuk itu, ruang kerja pengawasan ini harus memiliki batasan-batasan yang jelas, berupa tujuan dan ruang lingkup pengawasan, bentuk dan jenis pengawasan, tata cara menyelenggarakan pengawasan, dan pejabat atau badan yang berwenang melakukan pengawasan. ${ }^{34}$

Jika ditinjau dari tiga ajaran konsep otonomi daerah yaitu sistem rumah tangga secara materiil, formil, dan riil, sistem rumah tangga riil adalah yang paling cukup. Hubungan antara UU Pemda 2004 dengan UU Pemda 2014 menunjukkan bahwa terdapat perubahan ajaran konsep otonomi daerah yang akan berimplikasi pada sistem pengawasannya. Pada UU Pemda 2004, dianut sistem rumah tangga formil

34 M. Nur Sholikin, dkk., Laporan Kajian Implementasi Pengawasan Perda Oleh Pemerintah Dan Mahkamah Agung, Jakarta: Pusat Kajian Hukum dan Kebijakan Indonesia, 2011, hlm. 9. 
dan riil karena pengaturan tentang pembagian kewenangan antara pemerintah pusat dengan pemerintah daerah diatur dalam undang-undang secara umum. Pada UU Pemda 2014, dianut sistem rumah tangga materiil karena seluruh pembagian kewenangan pemerintah pusat dan pemerintah daerah ditentukan secara rinci dan detail seperti yang telah diulas pada penjelasan sebelumnya.

\section{E. Penutup}

Pada UU Pemda 2014, hubungan kewenangan antara pemerintah pusat dan daerah yang berimplikasi pada pengawasannya, khususnya pengawasan preventif cenderung dilaksanakan terlalu ketat, karena pemerintah pusat dinilai terlalu besar campur tangan dalam praktik pelaksanaan kewenangan pemerintah daerah secara ideal. Sehingga sistem pengawasan sebagai implikasi dari kewenangan pemerintah pusat dan daerah menurut UU Pemda 2014 kurang tepat, karena cenderung melemahkan otonomi dan menuju ke arah resentralisasi. Hal ini cukup bertentangan dengan esensi otonomi daerah yang seharusnya mengedepankan porsi pemerintah daerah untuk mengurus segala kebutuhan daerahnya sesuai dengan kondisi khusus yang dimiliki daerah tersebut. Oleh karena itu, pemerintah daerah sebaiknya diberi keleluasaan dalam mengurus daerah demi kesejahteraan masyarakat di daerah. Pada pengawasan preventif dapat mengikutsertakan peran aktif masyarakat di daerah mengenai substansi kebijakan daerah.

\section{Daftar Pustaka}

\section{Buku}

Ahmad Yani, Hubungan Keuangan Antara Pemerintah Pusat dan Daerah di Indonesia, cetakan kelima, Raja Grafindo Persada, Jakarta, 2013.

Arief Hidayat dan Adji Samekto, Kajian Kritis Penegakan Hukum Lingkungan di Era Otonomi Daerah, Badan Penerbit Universitas Diponegoro, Semarang, 2007.

Bagir Manan, Menyongsong Fajar Otonomi Daerah, Pusat Studi Hukum Fakultas Hukum UII, Yogyakarta, 2004.

Bungaran Antonius Simanjuntak, Iswan, Kaputra (eds.), Dampak Otonomi Daerah di Indonesia, Merangkai Sejarah Politik dan Pemerintahan Indonesia, Cetakan Pertama, Yayasan Pustaka Obor Indonesia, Jakarta, 2013.

I Wayan Parsa, Pengawasan Pemerintah (Pusat) Dalam Penyelenggaraan Pemerintahan Daerah, Universitas Airlangga, Surabaya, 2005.

Internasional IDEA, Penilaian Demokratisasi di Indonesia, Internasinal IDEA, Stockholm, 2000.

Irene Mariane, Kearifan Lokal Pengelolaan Hutan Adat, Raja Grafindo Persada, Jakarta, 2014. 
Jazim Hamidi, Mustafa Lutfi, Dekonstruksi Hukum Pengawasan Pemerintahan Daerah, UB Press, Malang, 2011.

Kharul Muluk, Desentralisasi dan Pemerintahan Daerah, Bayumedia Publishing, Malang, 2005.

King Faisak Sulaiman, Dialektika Pengujian Peraturan Daerah Pasca Otonomi Daerah, Pustaka Pelajar, Yogyakarta, 2014.

M. Nur Sholikin, dkk, Laporan Kajian Implementasi Pengawasan Perda Oleh Pemerintah Dan Mahkamah Agung, Pusat Kajian Hukum Dan Kebijakan Indonesia, Jakarta, 2011.

Rawan Soejito, Hubungan Pemerintah Pusat dan Pemerintah Daerah, Rineka Cipta, Jakarta, 1990.

S. F. Marbun, Otonomi Daerah 1945-2010: Proses Dan Realita Perkembangan Otoda, Sejak Jaman Colonial Sampai Saat Ini, cetakan kedua, Pustaka Sinar Harapan, Jakarta, 2010.

S. F. Marbun, dkk., Dimensi-Dimensi Hukum Administrasi Negara, UII Press, Yogyakarta, 2004.

Steinberg, Sheldon S., David T. Austern, Government Ethics, and Managers; Penyelewengan Aparat Pemerintah (terjemahan Suroso), Remaja Rosdakarya, Bandung, 1999.

Soewargono Prawirohardjo, Prinsip-Prinsip Pemerintah Umum Dalam Pelaksanaan

Pemerintahan di Daerah, Pemerintahan Daerah di Indonesia, Masyarakat IImu Pemerintahan Indonesia (MIPI), Jakarta, 2009.

Suko Wiyono, Otonomi Daerah Dalam Negara Hukum Indonesia, Faza Media, Jakarta, 2006.

Suyamto, Beberapa Aspek Pengawasan di Indonesia, Jakarta, Sinar Grafika.

Widodo Ekathahjana, Pengujian Peraturan Perundang-Undangan Dan Sistem

Peradilannya di Indonesia, Pustaka Sutra, Jakarta, 2008.

\section{Dokumen Lain}

Jurnal Hukum No Edisi Khusus Vol. 16 Oktober 2009.

\section{Dokumen Hukum}

Undang-Undang Dasar Negara Republik Indonesia Tahun 1945.

Undang-Undang No. 32 Tahun 2004 Tentang Pemerintahan Daerah.

Undang-Undang No. 23 Tahun 2014 Tentang Pemerintahan Daerah. 